1 Slow build-up of turbidity currents triggered by a moderate

2 earthquake in the Sea of Marmara

3

4 Pierre Henry ${ }^{1}$, M Sinan Özeren ${ }^{2}$, Nurettin Yakupoğlu ${ }^{3}$, Ziyadin Çakir ${ }^{3}$, Emmanuel de

5 Saint-Léger $^{4}$, Olivier Desprez de Gésincourt ${ }^{4}$, Anders Tengberg ${ }^{5}$, Cristele Chevalier ${ }^{6}$,

6 Christos Papoutsellis ${ }^{1}$, Nazmi Postacıoğlư ${ }^{7}$, Uğur Dogan ${ }^{8}$, Hayrullah Karabulut ${ }^{9}$,

7 Gülsen Uçarkuş ${ }^{3}$, M Namık Çağatay ${ }^{3}$

8

9 'Aix Marseille Univ, CNRS, IRD, INRAE, Coll France, CEREGE, Aix-en-Provence,

10 France, ${ }^{2}$ Istanbul Technical University, Eurasia Institute of Earth Sciences, Maslak, Istanbul, Turkey, ${ }^{3}$ Istanbul Technical University, Geological Engineering Dept., Maslak, Istanbul, Turkey, ${ }^{4} \mathrm{CNRS}$, DT INSU, Parc national d'instrumentation océanographique, Plouzané, France, ${ }^{5}$ Aanderaa Data Instruments AS, Bergen, Norway, ${ }^{6}$ Aix Marseille Univ, CNRS, IRD, MIO, Aix-en-Provence, France, ${ }^{7}$ Istanbul Technical University, Physics Dept., Maslak, Istanbul, Turkey, ${ }^{8}$ Yıldız Technical University, Geomatic Engineering Dept., Istanbul, Turkey, ${ }^{9}$ Bogazici University, KOERI, Istanbul, Turkey

Correspondence to: Pierre Henry (henry@cerege.fr)

Abstract. Earthquake-induced submarine slope destabilization is known to cause debris flows and turbidity currents, but the hydrodynamic processes associated with these events remain poorly understood. Records are scarce and this notably limits our ability to interpret marine paleoseismological sedimentary records. An instrumented frame comprising a pressure recorder and a Doppler recording current meter deployed at the seafloor in the Sea of Marmara Central Basin recorded consequences of a $\mathrm{M}_{\mathrm{w}}=5.8$ earthquake occurring Sept 26, 2019 and of $\mathrm{M}_{\mathrm{w}}=4.7$ foreshock two days before. The smaller event caused sediment resuspension but no strong current. The larger event triggered a complex response involving a mud flow and turbidity currents with variable velocities and orientations, which may result from multiple slope failures. A long delay of 10 hours is observed between the earthquake and the passing of the strongest turbidity current. The distance travelled by the sediment particles during the event is estimated to several kilometres, which could 
account for a local deposit on a sediment fan at the outlet of a canyon, but not for the covering of the whole basin floor. We show that after a moderate earthquake, delayed turbidity current initiation may occur, possibly by ignition of a cloud of resuspended sediment. Some caution is thus required when tying seismoturbidites with earthquakes of historical importance. However, the horizontal extent of the deposits should remain indicative of the size of the earthquake.

1. Introduction

Triggering of mass flows and turbidity currents by earthquakes is a hazard that can damage infrastructure at the seafloor (Heezen et al., 1954) and may enhance coseismic tsunami generation (Okal and Synolakis, 2001; Synolakis et al., 2002; Hebert et al., 2005; Ozeren et al., 2010). It is often considered that a peak ground acceleration (PGA) of the order of $0.1 \mathrm{~g}$ is needed for an earthquake to trigger a submarine slope instability (Dan et al., 2008; Nakajima and Kanai, 2000). However, a global compilation of cable breaks shows that, exceptionally, mass flow have been triggered by individual earthquakes of $M_{w}$ as low as 3.1 (with $P G A \approx 10^{-3} \mathrm{~g}$ ) and that, on the other hand many $M_{w}>7$ have failed to break cables, notably in zones (e.g. Japan Trench) where sediment input is relatively low and earthquakes frequent (Pope et al., 2016). In the Mediterranean region, the threshold is reportedly around $\mathrm{M}_{\mathrm{w}}=5$.

In spite of this high regional variability, turbidite deposits in several seismically active zones have been used successfully as paleoseimological event markers (Goldfinger et al., 2003, 2012; McHugh et al., 2014; Ikehara et al., 2016). This requires distinguishing between seismoturbidites, caused by earthquakes and related mass wasting events, from those resulting from other processes (e.g. floods, storms, sediment loading). Seismoturbidites are generally described as turbidite-homogenites where a basal silt-sand bearing layer is overlaid by a layer of apparently homogenous mud with small or gradual, if any, variations in grain size and chemical composition 60 (Polonia et al., 2013; McHugh et al., 2011; Çağatay et al. 2012; Eriş et al., 2012; 61 Gutierrez-Pastor et al., 2013; Beck et al., 2007). In lakes and closed basins several 62 characteristics of deposits following earthquake or landslides, such as the sharp boundary between turbidite and homogenite layers, the alternation of silt/sand and mud laminae within a single turbidite-homogenite unit and presence of bi-directional cross- or flaser- bedding have been interpreted as indicators of deposition from oscillatory currents associated with seiches or turbidity current reflection (Beck et al., 
67 2007; Çağatay et al. 2012; McHugh et al., 2011). Seismoturbidites on ocean margins 68 have fairly similar characteristics to those in closed basins but their layering has been 69 interpreted differently, as a consequence of confluence (stacked or amalgamated 70 turbidites) or current speed variations (multi-pulsed turbidites) (Gutierrez-Pastor et al., 71 2013; Nakajima and Kanai, 2000; Goldfinger et al., 2003). There is currently a lack of 72 in situ records that could substantiate inferred hydrodynamic processes. Monitoring 73 experiments brought records of representative cases of turbidity currents flowing in 74 submarine canyons and initiated by meteorological events and occasionally by 75 landslides (Azpiroz-Zabala et al., 2017; Khripounoff et al., 2012; Xu et al., 2004, 2010; 76 Liu et al., 2012; Hughes Clarke, 2016). Oscillatory currents resulting from internal 77 waves have been recorded after landslides in lakes (Brizuela et al., 2019). On the other 78 hand, most information on earthquake-triggered events is still indirect based on cable ruptures (e.g. Pope, 2017; Hsu et al., 2008), combined with geomorphological and 80 sedimentological observations (Cattaneo et al., 2012; Piper et al., 1999), and information from displaced instruments (Garfield et al., 1994). In Japan, in situ records of pressure and temperature were obtained from displaced OBSs after the Tohoku $2011 M_{w} 9.1$ earthquake (Arai et., 2013), and from cabled observatories after the 84 Tokachi-Oki $2003 M_{w} 8.3$ earthquake (Mikada et al., 2006) and after a moderate (M 85 5.4) earthquake off Izu Penninsula (Kasaya et al., 2009). After the large events, strong currents of more than $1 \mathrm{~m} / \mathrm{s}$ were implied starting 2-3 hours after the earthquake with no indication of oscillation or pulsing. In the off-Izu case a mudflow was observed with a camera 5 minutes after the earthquake and followed 15 minutes later by a change in current direction and speed.

We here present results from an instrumental deployment at the seafloor that accidentally recorded the consequences of earthquakes that occurred 09/24/2019 and 09/26/2019 in the Sea of Marmara with respective magnitudes 4.7 and 5.8 (Figure 1A). Holocene seismoturbidite records in the Sea of Marmara basins display a recurrence of 200 to 300 years, that roughly corresponds to the recurrence interval of Mw>7 earthquakes (McHugh et al., 2006, 2014; Drab et al., 2012, 2015; Yakupoğlu et al., instrument demonstrate that this moderate earthquake triggered turbidity currents.

98 However, the instrument suffered a rather complex sequence of disturbances and a

9910 hours delay is observed between the earthquake and the recording of peak current. 
We here propose a scenario which could explain the observations and discuss their implications for the understanding of seismoturbidite records.
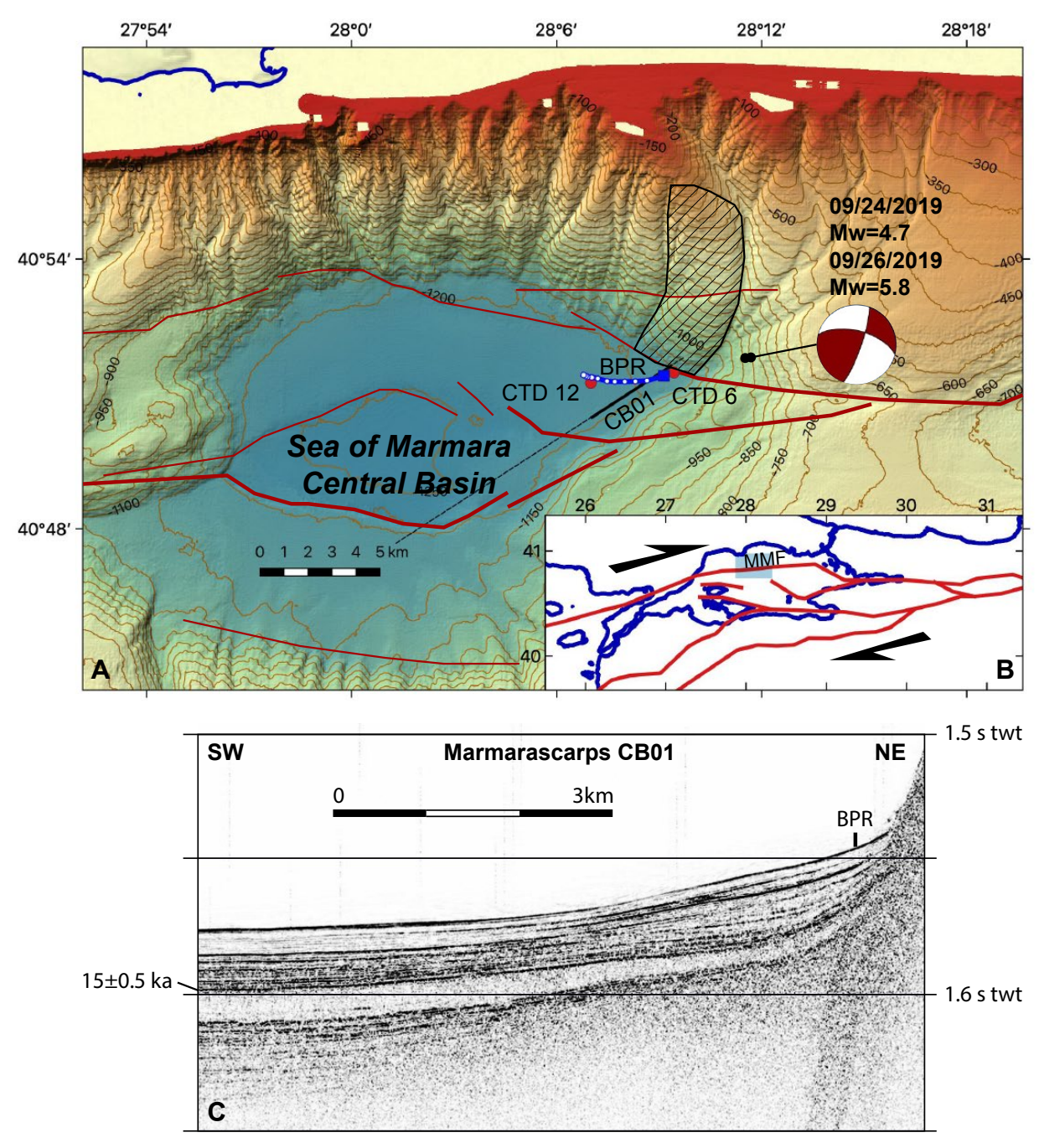

Figure 1. Context of instrumental deployment. (A) bathymetric map of the Sea of Marmara Central Basin with simplified fault geometry (in red). The hatched zone is a suspected mass wasting zone (Zitter et al., 2012). Location of instrumented frame comprising bottom pressure recorder (BPR) and doppler current meter is indicated by blue square. The blue banana with white dots represents the calculated trajectory of a sedimentary particle during the waning phase of the turbidity current. Red dots are CTD profiles 6 and 12 shown in supplementary material S1. Epicenter location of 
earthquakes and the focal mechanism of the main shock are indicated. (B) Location of study area. North Anatolian Fault system is shown in red. MMF is the Main Marmara Fault. (C) Sediment sounder profile from Marmarascarps cruise (Armijo and Malavieille, 2002). Indicative age of reflector from Beck et al. (2007). The instrument (BPR) was deployed on a depositional fan at the base of slope and canyon outlet that differ in character from the hemipelagite / turbidite-homogenite sequence in the basin. resonant water column oscillations (seiches) at various locations in the Sea of Marmara with the aim to improve tsunami models (Henry et al., 2021). An instrumented frame was thus deployed at $40.8568^{\circ} \mathrm{N}, 28.1523^{\circ} \mathrm{E}$ and $1184 \mathrm{~m}$ water depth in the Central Basin on May 9, 2019 and recovered 6 months later (11/19/2019) (Figure 1A). This site is located at the outlet of a branched canyon system originating from the edge of the continental shelf (Figure 1). Sediment sounder profiles indicate a depositional fan or lobe is present at this location (Figure 1C). The short canyons observed on the relatively steep sedimented slope $\left(\approx 10^{\circ}\right)$ of the Sea of Marmara deep basins are presumably fed by instabilities of the canyon heads and walls (Zitter et al. 2012; Çağatay et al., 2015). In addition, the slope west of the canyons immediately north of the deployment site hosts a mass wasting feature covering about $24 \mathrm{~km}^{2}$ (Zitter et al. 2012). The Main Marmara Fault (MMF, Figure 1B), is defined as the part of the northern branch of the North Anatolian Fault system crossing the Sea of Marmara (Le Pichon et al., 2001, 2003). A splay of the MMF runs along the base of this slope (Armijo et al., 2002; Grall et al., 2012; Sengor et al., 2014). The 09/24/2019 and 09/26/2019 earthquakes occurred beneath the canyon system and their epicenters are located 5 $\mathrm{km}$ ENE of the instrument, less that $500 \mathrm{~m}$ apart (Figure 1). The rupture occurred within

137 displacement zone of the Main Marmara Fault. The focal mechanism and aftershock

138 distribution indicate right-lateral strike-slip with a reverse component (Karabulut et al., 139 2021). The rupture did not reach the seafloor, nor caused a tsunami. For instance, tidal 140 gauge records obtained at Marmara Ereglisi do not deviate more than $1 \mathrm{hPa}$ from a 141 fitted tidal model. 
142 The instrumentation on the frame comprises (1) an RBR bottom pressure recorder 143 (BPR) with a Paroscientific 0-2000 m Digiquartz sensor, (2) a Seaguard recording 144 current meter (RCM) equipped with a Z-pulse 4520 Doppler current meter operating in 145 the 1.9-2 MHz frequency range and other sensors: temperature, pressure (tide sensor 146 Aanderaa 5217), conductivity (Aanderaa 4319), oxygen (Aanderaa optode 4330) 147 (Figure 2). The RBR pressure recording interval was set to $5 \mathrm{~s}$ and that of the Seaguard $148 \mathrm{RCM}$ to one hour for all sensors. The Doppler current meter worked in burst mode, 149 averaging 150 pings taken every second at the end of each one-hour recording interval. 150 The SeaGuard instrument was fixed on the upper part of the frame $1.5 \mathrm{~m}$ above the 151 seafloor and emit 4 narrow $\left(2^{\circ}\right)$ beams at orthogonal directions in a plane, parallel to 152 the seafloor if the frame is standing upright, and measures Doppler backscatter in cells 153 extending 0.5-to-2 meters from the instrument (Figure 3). The instrument was set in forward ping mode, so that only data from sensors measuring a positive Doppler shift, upstream currents moving toward the instrument, are used to calculate current speed. The tide sensor is a piezoresistive sensor with a specified accuracy comparable to that of the Digiquartz sensors (4kPa for a 0-2000 m sensor vs. $2 \mathrm{kPa}$ for a Digiquartz sensor with the same range) and $0.2 \mathrm{hPa}(2 \mathrm{~mm})$ resolution and comprises a temperature sensor of $0.2^{\circ} \mathrm{C}$ accuracy and $0.001^{\circ} \mathrm{C}$ resolution. The tide sensor averages pressure measured at a $2 \mathrm{~Hz}$ sampling rate over $300 \mathrm{~s}$ at the end of each one-hour time interval. the tide sensor was checked against an atmospheric reference between deployments and found to have a minimal drift, less than $1 \mathrm{hPa}$.

As we will show that the 09/24/2019 earthquake caused the instrumented device to lay on its side for several hours and then straighten up, understanding the setup of the seafloor device and its stability is important (Figure 2B). The frame is made of aluminium and has 6 rigidly bound flotation spheres of $25 \mathrm{~kg}$ buoyancy each. The net weight of the instrumented frame in water is $-80 \mathrm{~kg}$. The frame is rigidly attached to a 12 -cm-thick $1.5 \times 1.3 \mathrm{~m}$ concrete slab, weighting $300 \mathrm{~kg}$ in water. The assembly of the heavy slab and buoyant frame is stable in upright position in the water and on the seafloor. Moreover, it is estimated that a current of $1 \mathrm{~m} / \mathrm{s}$ would cause a total horizontal drag of $75 \mathrm{~kg}$ when the device is in upright position, which is insufficient to destabilize

172 it. If a stronger current, or other external forces, cause the assembly to tilt and lay on 173 one side, the moment of the gravity and buoyancy forces should straighten the device 174 back to upright position when these external forces are removed. 
175 Measurement of current speed and direction by a tilted instrument is a related issue that we here consider. The orientation and attitude of the Seaguard RCM is measured

177 with a 2-component accelerometer and a magnetic compass and the recorded data

178 include tilt in $X$ and $Y$ direction and the heading of the $X$ axis. Tilt $X$ and $Y$ components

179 are factory calibrated from $-35^{\circ}$ to $+35^{\circ}$ with an accuracy of $1.5^{\circ}$. Tests performed in

180 the laboratory (see supplementary material, Figure S1) showed that tilt information

181 remains consistent outside this range, even when the instrument is upside down. Tilt

182 measurements are accurate within $3^{\circ}$ up to $60^{\circ}$ but saturate at about $80^{\circ}$ (Figure S2).

183 Uncertainty on heading also increases with tilt, especially when the instrument is tilted

184 toward the X-direction. However, measured heading remains $\pm 20^{\circ}$ of true heading for

185 a tilting of up to $60^{\circ}$ (Figure S3). The current measured in the instrument plane is

186 corrected for tilt assuming current is horizontal. As far as this approximation is valid,

187 the current record should in principle remain fairly accurate when the instrument is

188 tilted beyond the normal range of operation ( $\pm 35^{\circ}$ degree) and at least to $60^{\circ}$. However,

189 the compass was not calibrated for an upside-down configuration. If the top of the

190 instrument would happen to be oriented downward, the measured current direction will

191 be unreliable, even though the absolute speed may still be correctly estimated. Another

192 problem may arise if one of the Doppler sensors is facing down into the sediment so

193 that its measurement cell is below the seafloor. If the sensor pointing upward in the

194 opposite direction is recording a negative Doppler shift, this value will be ignored in the

195 forward ping mode. In this case, the measurement retained to calculate current velocity

196 will correspond to noise from the sensor facing toward the seafloor. In all situations, it

197 remains possible to recalculate the sensor readings retained by the calculator from the

198 current velocity and orientation parameters recorded by the instrument, and thus

199 assess the reliability of data.

200 

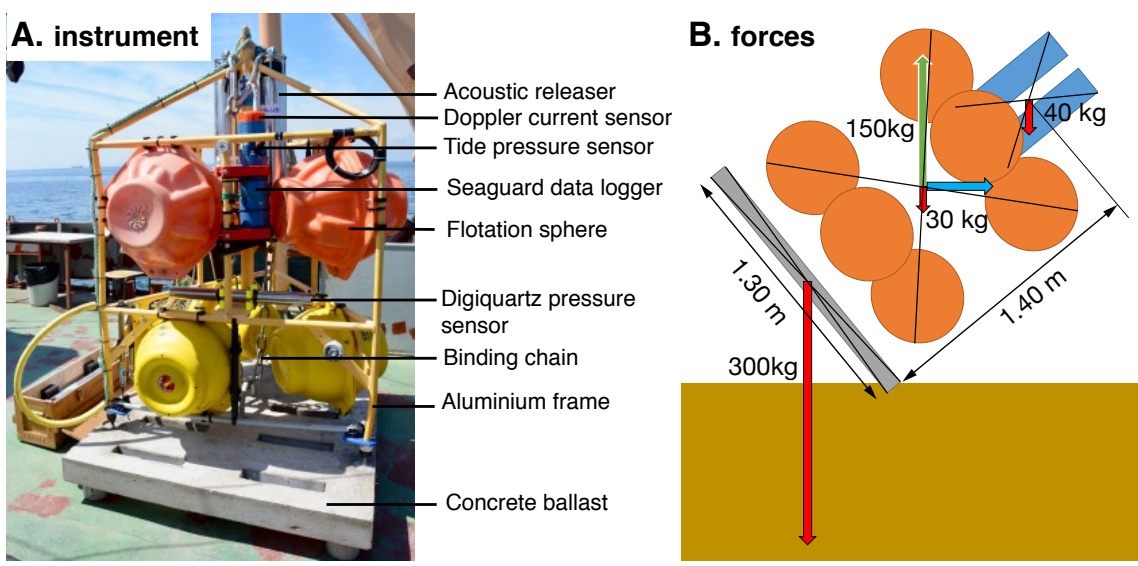

Figure 2. Instrumented frame. (A) photo of the instrumented frame before deployment. (B) Sketch showing forces applied to the elements of the instrumented frame in water. The red arrows represent the weight in water of the cement ballast, of the instrumented frame and of the acoustic release system on top. The green arrow represents the buoyancy of the flotation spheres. The blue arrow represents the current drag, which depends on current speed and instrument tilt.

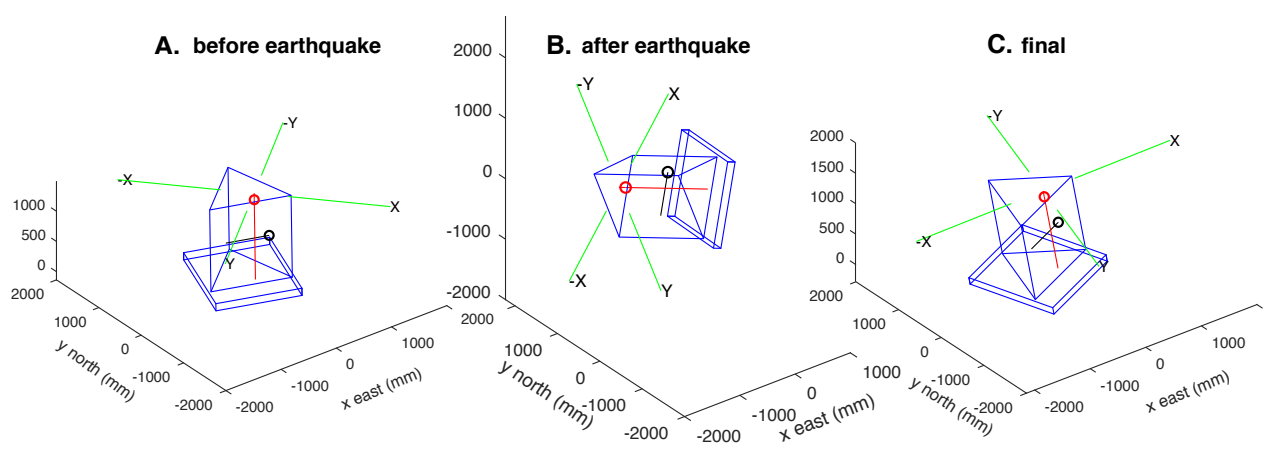

Figure 3. Reconstruction of frame position based on instrument tilt-meter and compass data: $(A)$ before the earthquake; (B) Tilted, between, 25 minutes and 10.5 hours after earthquake; (C) back in nearly upright position 11 hours after earthquake. Position of Digiquartz pressure sensor (black circle), Aanderaa tide sensor (red circle) and Doppler current meter beam cells (green segments)

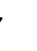




\section{Results and interpretations}

\subsection{Pressure and tilt records}

Pressure sensors are sensitive to pressure variations caused by P-waves and Digiquartz sensors are also intrinsically sensitive to acceleration, but to a small extent, $160 \mathrm{hPa} / \mathrm{g}$ for an instrument with $20 \mathrm{MPa}$ range according to the calibration report. Small earthquakes are detected as pressure spikes, while oscillations are recorded after large earthquakes. The $M_{w} 4.709 / 24 / 2019$ caused a short pressure transient of $25 \mathrm{hPa}$ at 08:00:26 followed by small pressure oscillations of less than $3 \mathrm{hPa}$ amplitude decaying over a few minutes. The seismic wave train from the $M_{w} 5.8,09 / 26 / 1919$ earthquake is recorded by the Digiquartz pressure sensor as oscillations, initiated by a pressure drop of $65 \mathrm{hPa}$ between 10:59:22 and 10:59:26 (Figure 4). For the sampling interval of $5 \mathrm{~s}$ used in this setup, the recorded signal is aliased, which precludes quantitative interpretation in term of velocity or acceleration. However, the initial pressure drop after the 09/26/1919 earthquake may indicate a negative polarity of the first $P$ arrival at the instrument site, located on an ascending ray-path.

Twenty-five minutes after the $M_{w} 5.8$, earthquake, a new disturbance of the pressure sensor is observed at 11:23:41. The pressure then progressively increases by $30.9 \mathrm{hPa}$ in 15 seconds between 11:24:46 and 11:25:01 before stabilizing. Over the corresponding one-hour-time-interval between successive records, the Seaguard RCM, initially subvertical (tilt less than $2^{\circ}$ ), acquires a strong tilt (Figure 3). At 11:57:48, measured tilt is $-65^{\circ}$ along the $\mathrm{X}$-axis and $+19^{\circ}$ along the $\mathrm{Y}$-axis, with $\mathrm{X}$-axis in a N161 ${ }^{\circ}$ azimuth and these values remain constant $\pm 2^{\circ}$ over the next 10 hours, corresponding to an absolute tilt of $68^{\circ}$ (Figure 4). The tilting of the instrument causes the Digiquartz and Tide sensors to record different pressure variations because they are located at different positions on the frame (Figure 2). Moreover, the pressure readings by the Digiquartz sensor also depend on its orientation relative to Earth gravity. Pressure at the Tide sensor location increases about $100 \mathrm{kPa}$, corresponding to a $1 \mathrm{~m}$ drop and indicating that the frame was then practically laying on its side. Ten hours later, the device apparently straightens itself in about 5 seconds, between 21:28:29 and 21:28:34 as indicated by a rapid pressure variation. After that, the recorded tilt parameters are moderate and stabilize at $-11.5^{\circ}$ for the $\mathrm{X}$-axis and $5.3^{\circ}$ for the $\mathrm{Y}$-axis, with X-axis in a N105.3 azimuth. 
The $M_{w} 4.7$ earthquake caused minor disturbances of the attitude of the instrument, with variations of tilt and heading of less than $0.5^{\circ} . A M_{w} 3.6$ foreshock of the $M_{w} 5.8$ occuring 26/09/2019 at 7:32 also caused minor disturbances. These indicate that the seafloor was sensitive to ground shaking caused by these small earthquakes, however, this did not cause the device to sink into the sediment. Changes of pressure baseline of the digiquartz sensor between before and after these earthquake are difficult to resolve, and correspond to less than $5 \mathrm{~mm}$ vertical displacement for the first event and less than $2 \mathrm{~mm}$ for the second one.

258
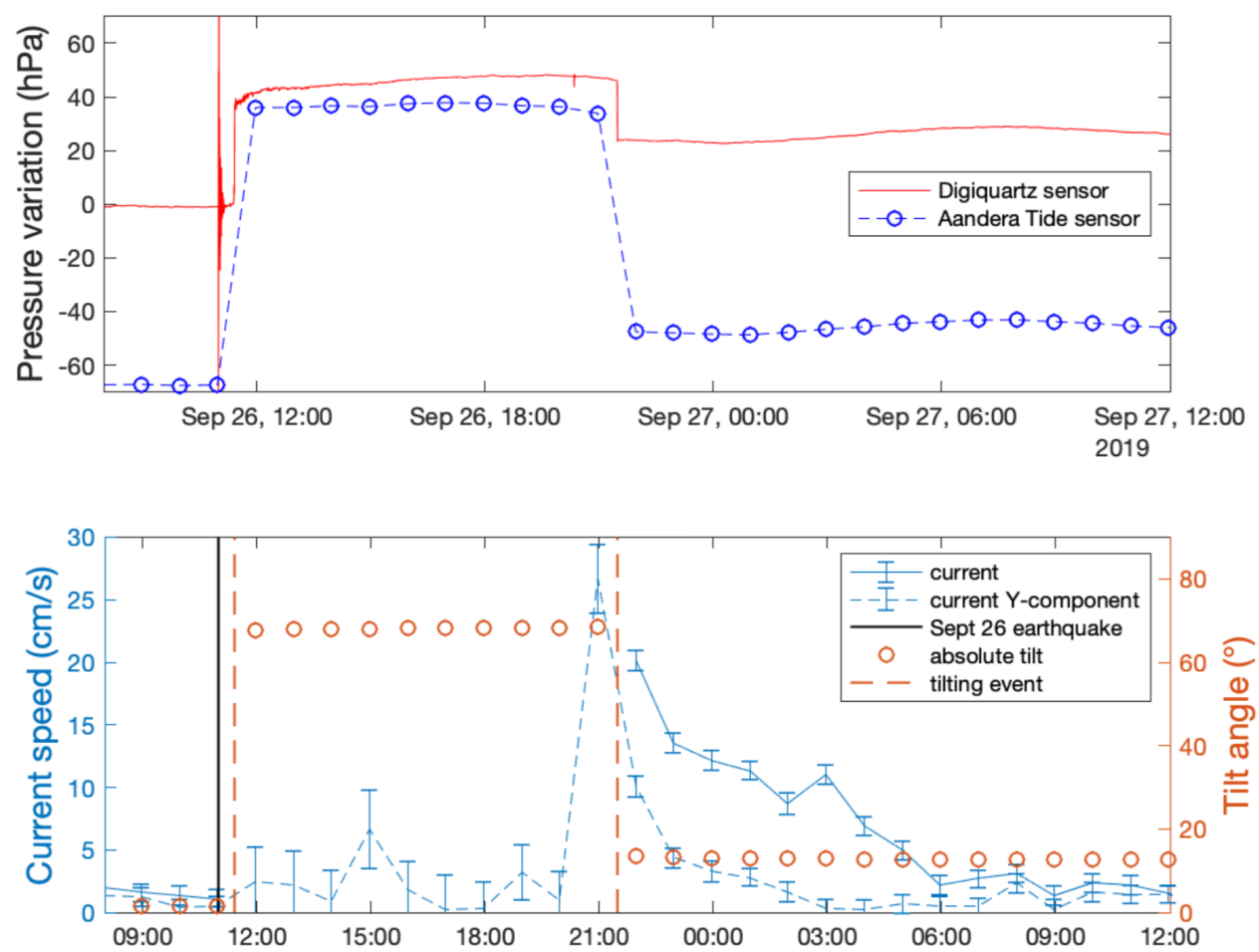

Figure 4. Time series around the time of occurrence of a $M_{w} 5.8$ earthquake; (top) pressure variations recorded by two instruments on the instrumented frame; (bottom) current and tilt data recorded by Seaguard RCM. Between the tilting events only one component of the doppler current meter functioned reliably ( $\mathrm{Y}$-component oriented N200) and is here reported. 

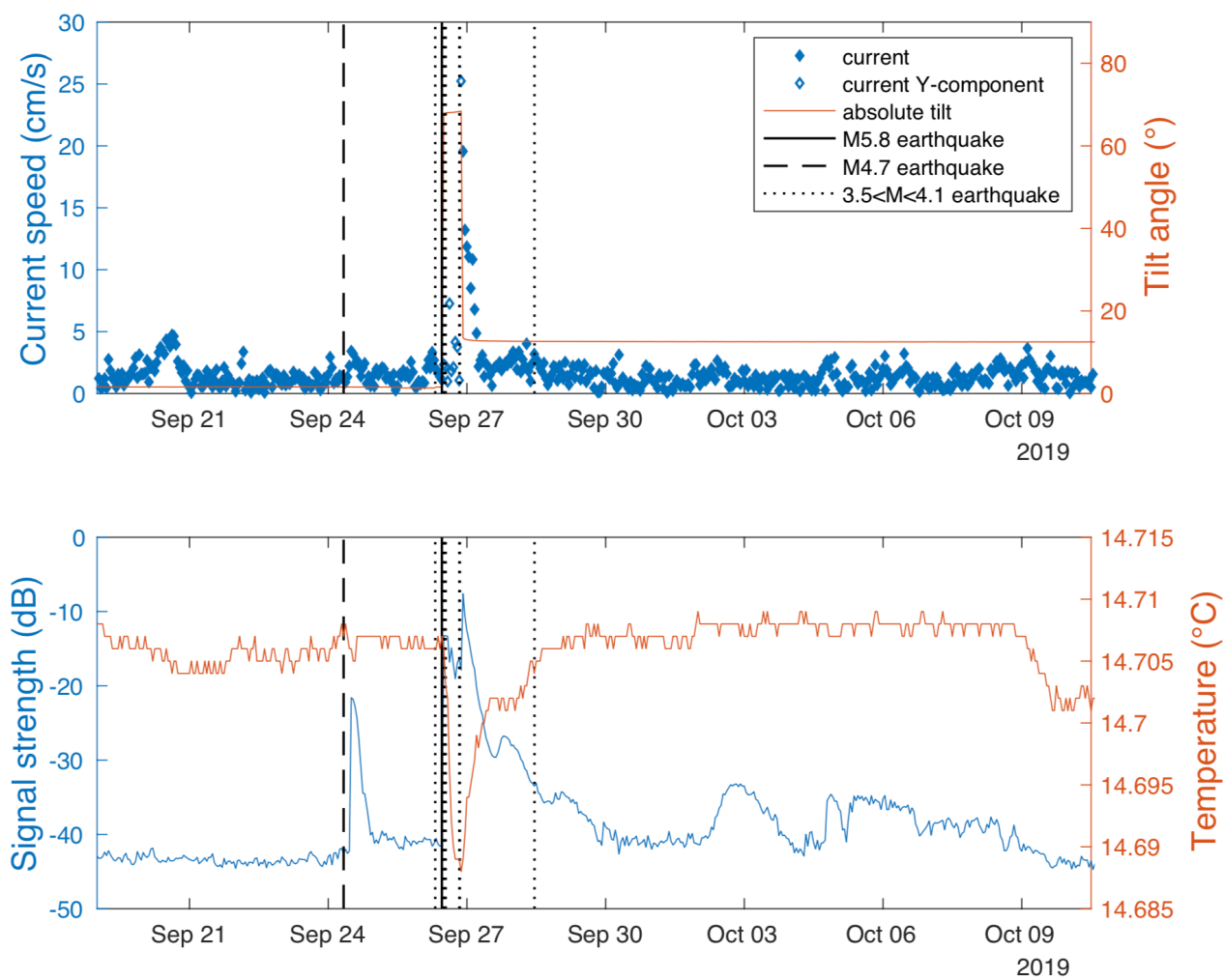

265

Figure 5. Time series acquired with Seaguard RCM during the September 2019 seismicity cluster; (top) current speed and tilt; (bottom) backscatter signal strength and temperature.

\subsection{Current records and possible causes of tilting}

The $M_{w} 4.7$ 09/24/2019 earthquake was followed by a small increase of current strength peaking at $3.4 \mathrm{~cm} / \mathrm{s}$ at noon, 4 hours after the earthquake (Figure 5). Comparable events in term of duration and strength occurred spontaneously 09/20/2019 (with currents up to $4.7 \mathrm{~cm} / \mathrm{s}$ ) and 09/26/2019 just before the main earthquake. During all three events the dominant current was from the east, thus coming from the direction of the canyon, but there is an important difference between the event that occurred after the earthquake and the two others. During that event a change in current direction occurred from eastward to westward between 10:57 and 11:57 while the current strength increased from $2.2 \mathrm{~cm} / \mathrm{s}$ to its peak value (Figure 6). During the other events, build-up was more progressive and did not involve a change in direction. A drift plot, calculated by summing velocity vectors over time, reproduces 

about $500 \mathrm{~m}$ and occurs in the 8 hours following the current inversion. Current direction
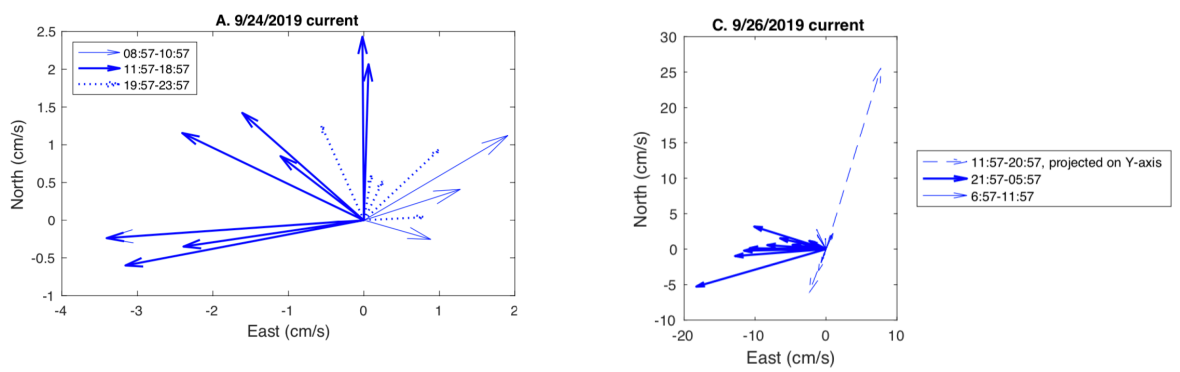

Figure 6. Current recorded after $M_{w} 4.7$ and $M_{w} 5.8$ earthquakes: (A) Current velocity arrows recorded every hour between 08:57 and 23:57 on 09/24/2019; (B) drift plot over the same time interval, the change of current direction and strength between 10:57 and 11:57 coincides with increasing backscatter strength (see figure 4), indicative of increased turbidity; (C) Current velocity arrows recorded every hour between 12:00 09/26/2019 and 06:00 09/27/2019. Dashed arrows show measurements acquired in the $Y$ direction when the instrument was strongly tilted (position $B$ in Figure 3), plain arrows when it was back in upright position (C in Figure 3); (D) drift plot over the same time interval, the dashed part corresponds to the strongly tilted position.

After the $M_{w} 5.809 / 26 / 1919$ earthquake, during the 10 hours period when the instrument remained strongly tilted, the instrument recorded currents varying both in speed and orientation, but some precautions are needed when interpreting these data. The current component measured by transducers along the $\mathrm{Y}$-axis of the instrument, oriented $\mathrm{N} 200^{\circ}$, probably remained accurate as the tilt along this axis is less than $20^{\circ}$ 
304 and the measurement cell remained above the bottom (Figure 2B). On the other hand, 305 the X-component may not be reliable as one of the sensors $\left(n^{\circ} 1\right)$ is oriented $65^{\circ}$ 306 upward in the $\mathrm{N} 160^{\circ}$ direction, and the oposite sensor $\left(n^{\circ} 3\right)$ is dipping $65^{\circ}$ downward 307 in the opposite $\left(\mathrm{N} 340^{\circ}\right)$ direction. Consequently, measurement cell $n^{\circ} 3$ lies within the 308 sediment and thus may only record noise. Moreover, because the Doppler current 309 sensor (DCS) is set in forward pinging mode, current speed is calculated with data 310 from sensors measuring positive doppler shifts only. This implies that if the current 311 component toward $\mathrm{N} 160^{\circ}$ is positive, sensor $\mathrm{n}^{\circ} 1$ will measure a negative shift and will 312 not be recorded. During the time inteval here considered, the mesured current 313 component in the X-direction (toward N160) is positive, which indicates that data from 314 sensor $n^{\circ} 4$ was used (Figure 7), and that is probably noise. It follows that the current 315 component along the Y-direction is the only one reliable. The horizontal current 316 measured along the $\mathrm{Y}$-axis changed sign several times during this time interval, and 317 reached peak values of $6.3 \mathrm{~cm} / \mathrm{s}$ toward N200 at 14:57:46, about four hours after the 318 earthquake, and of $25 \mathrm{~cm} / \mathrm{s}$ in the oposite direction at 20:57:46, the last measurement 319 before the instrument straightenned up. Other measurements on both axes remain 320 below $5 \mathrm{~cm} / \mathrm{s}$, but the absolute velocity may have been higher because this 321 measurement was only performed in one direction. Yet, these observartions suggest 322 that the strong current recorded before the instrument straightenned up played a role 323 in this event. Once the device got back in an upright position, it recorded a current 324 consistently flowing westward and progressively decreasing from $20 \mathrm{~cm} / \mathrm{s}$ to 325 background level $(2 \mathrm{~cm} / \mathrm{s})$ in 9 hours (Figure 4). During this waning phase, the current 326 drift is about $3.5 \mathrm{~km}$ in a westward direction (Figure 6). The drift estimated during the 327 first 10 hours after the earthquake, while the instrument was strongly tilted, is in the 328 opposite direction but may not be reliable. 

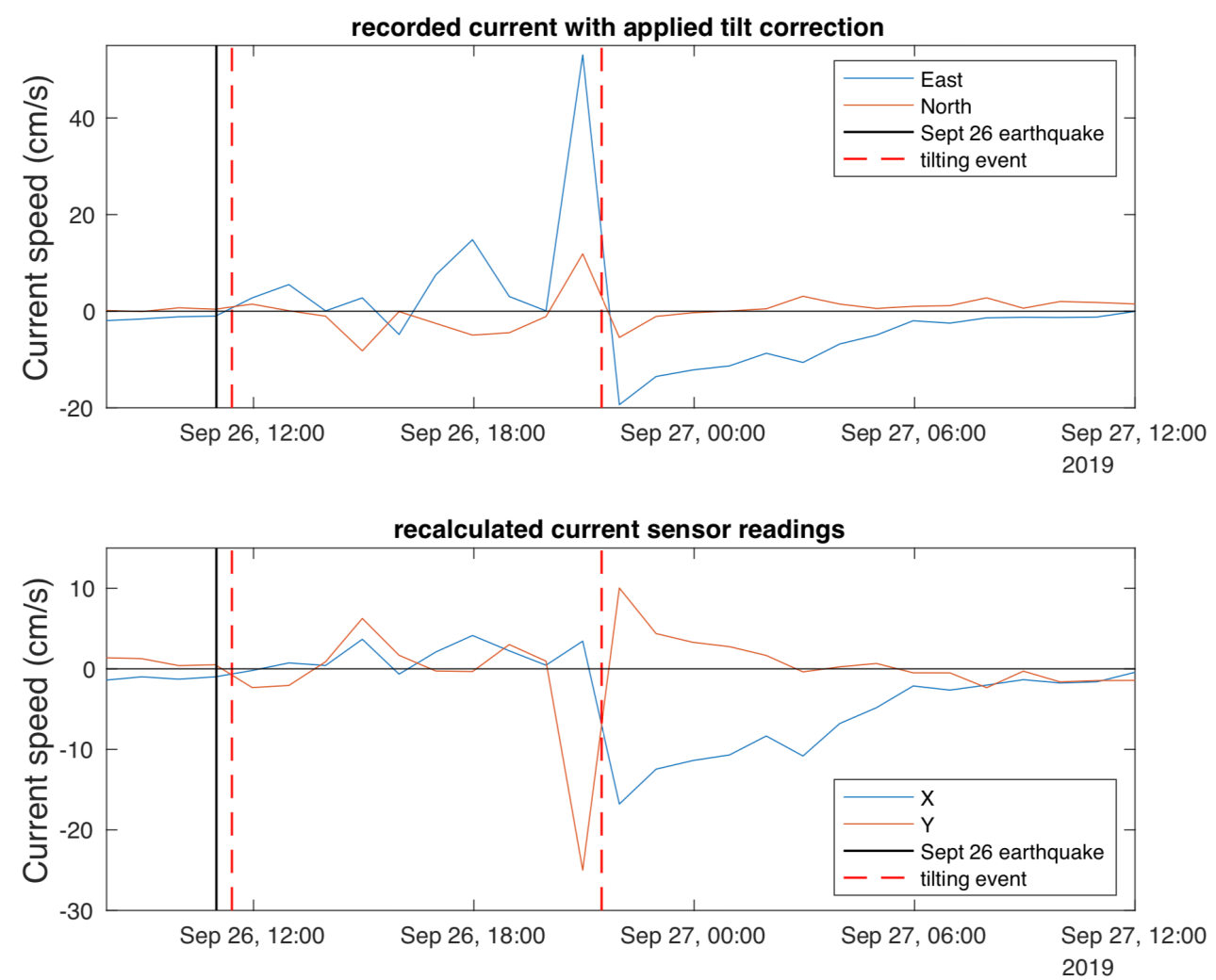

331 Figure 7. Current record acquired around the time of occurrence of a $M_{w} 5.8$ earthquake. A. Instrumental record, automatically corrected for tilt and heading. B. recalculated readings in the $\mathrm{X}$ and $\mathrm{Y}$ axis of the Doppler sensor (see text for interpretation).

The current speed in the first 2 hours after the main earthquake apparently remained low, at most $5-6 \mathrm{~cm} / \mathrm{s}$. It is thus unlikely that the tilt of the device was caused by strong currents. Some short burst of current may have been missed because of the 1 hour sampling interval, but this would not explain why the frame then remained stable in a tilted position for several hours. Local liquefaction of the sediment beneath the device is also an unlikely cause because the tilting of the instrument occurred 25 minutes after the earthquake. A mud flow originating from the basin slopes thus appears as a more likely cause. This hypothesis would also acount for the presence of sandy mud caked on the device in various places: on the frame feet, on the acoustic releasers, on the optode connector and also inside the plastic protection of a flotation 
sphere, from which bindings were broken and had to be repaired. On the other hand, the current speed in the $20-50 \mathrm{~cm} / \mathrm{s}$ range recorded before, as well as after, the time when the device straightened up is strong enough to cause erosion of mud or sand deposits. It may thus be hypothesized that erosion freed the device from the mud cover. The flotation spheres on the frame and the concrete ballast at its base exert a moment that should keep the assembly stable in an upright position unless the frame is loaded with sediment. $4.709 / 24 / 2019$ earthquake, backscatter increases sharply to $-22 \mathrm{~dB}$ between 11:00 and $12: 00$, and then decays to $-41 \mathrm{~dB}$ in 12 hours. The increase of backscatter coincides with a change of current direction and speed, indicating that the turbid cloud was brought to the instrument site by the current. However, the current speed of less than $4 \mathrm{~cm} / \mathrm{s}$ may have been insufficient to put the particles in suspension. There is no increase of backscatter on Sept 20 when stronger currents coming from the same direction, but not related with an earthquake, were recorded.

Backscatter strengh remain $41 \pm 1 \mathrm{~dB}$ the 1.5 days interval before the $M_{w} 5.8$

$5)$, which implies sand sized sediment was put in suspension soon after the earthquake

373 although the local current speed remained relatively low (about $5 \mathrm{~cm} / \mathrm{s}$ at most). After 374 the device went back to near vertical position, signal strengh reaches a maximum of $3757.6 \mathrm{~dB}$, which correspond to an amplitude ratio of 42 and an intensity ratio of 1800 376 compared to base level. Similar signal strength levels are typically reached with the Z-

377 Pulse sensor in highly turbid water such as in estuaries. During deep sea deployments 378 signal strength range more typically between -60 and $-40 \mathrm{~dB}$. After reaching peak value, 
backscattered signal strengh progressively decays to stabilise at about $-40 \mathrm{~dB} 3$ days (Figure 5). Several turbid events, with signal strength about $-35 \mathrm{~dB}$ are observed in October and associated with small increases in current velocity (up to $3-4 \mathrm{~cm} / \mathrm{s}$ ). It is unclear whether these passing clouds are residual turbidity from the earthquake. After October 9 , backscatter eventually returns to background level while temperature decreases by $0.007{ }^{\circ} \mathrm{C}$ over a few hours, indicating replacement of the water mass around the instrument.

3.4. Temperature record

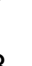

The Sea of Marmara is stratified, with a low salinity (20-22\%o) 20-30 m surface layer that displays strong seasonal temperature variability overlaying a high salinity (about $38 \%$ ) body of seawater at $14-15^{\circ} \mathrm{C}$ derived from the Aegean Sea (Beşiktepe et al., 1994). Within this body, the potential temperature generally decreases with depth, which would in principle imply that a turbidity current, flowing downward, should cause a small temperature increase. However, the deployment site is prone to seasonal cascading, so that the initial temperature structure may have been disturbed. Example of CTD profiles recorded in June 2007 (Henry et al., 2007) are shown in Figure 8. No CTD profile is available in Sept 2019, but variations in temperature and oxygen concentration associated with mild currents $(<5 \mathrm{~cm} / \mathrm{s})$ were recorded by the instrument in May-July 2019, and again on Sept 20.

404 Temperature then progressively increases to reach nearly the same value as before 405 the event. The small variation in temperature recorded indicates that the turbid water 406 originates from the deep-water body. The slight temperature decrease observed after 407 the earthquake can result from the mixing of a warmer bottom water layer with the bulk 408 of the deep-water layer. However, the observation of a temperature drop precludes 409 that the turbid water originates from depths less than $400 \mathrm{~m}$, as water present between $410400 \mathrm{~m}$ and the halocline is at a higher potential temperature than the deeper water 411 throughout the year (see Beşiktepe et al., 1994, and figure 8). Moreover, an inflow of 
412 water from closer to the surface should result in an increase in the $\mathrm{O}_{2}$ concentration in 413 the bottom water, but none is observed in the data.

414
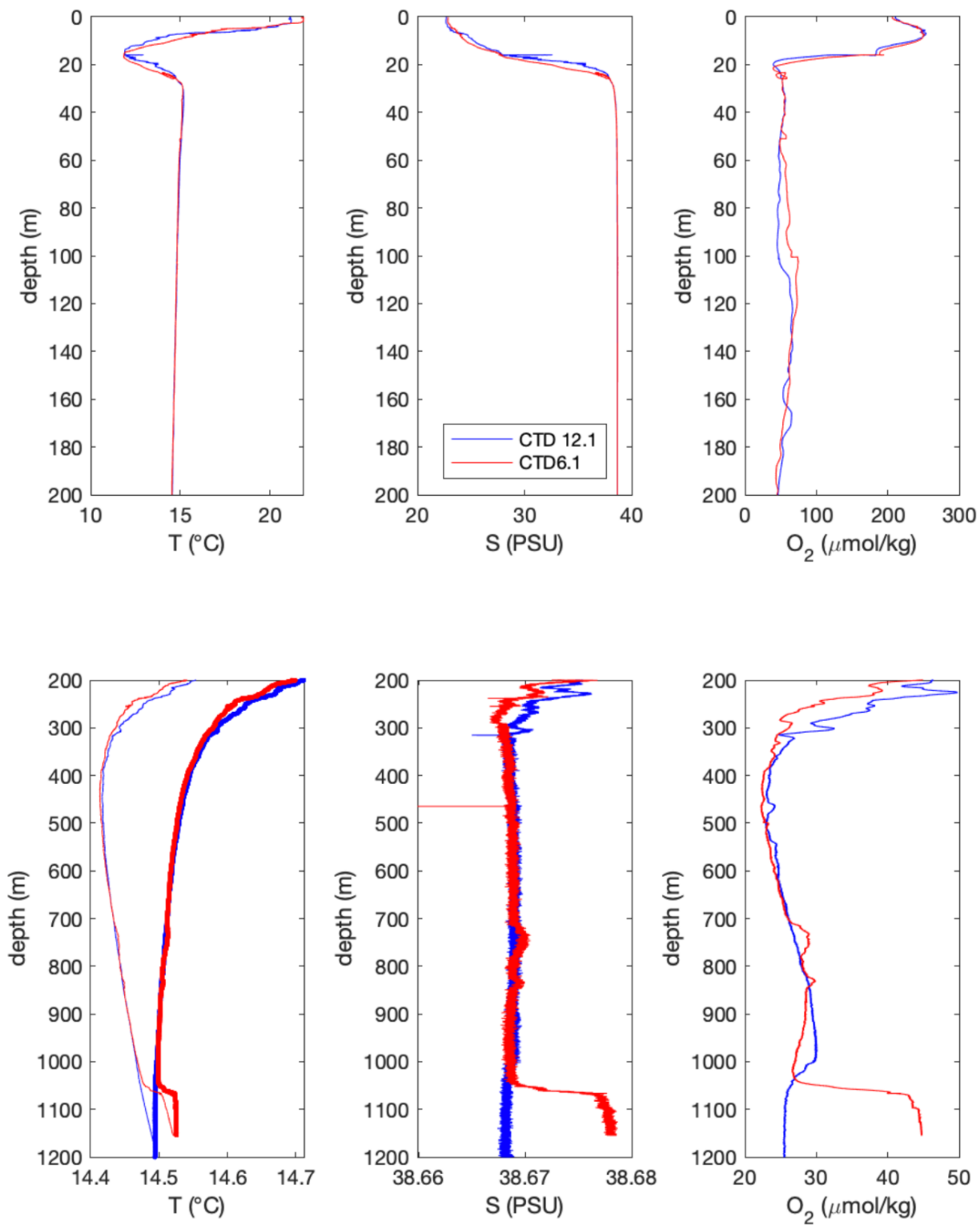

415

416 Figure 8. Depth plots of Temperature $\left({ }^{\circ} \mathrm{C}\right)$, Salinity (PSU) and oxygen concentration

$417(\mu \mathrm{mol} / \mathrm{kg})$ from CTD profiles acquired in the Sea of Marmara during Marnaut cruise of 418 Ifremer RV L'Atalante (Henry et al., 2007). On the lower temperature plot, thin lines 


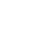

419 are measured values and thick lines are potential temperatures calculated at $1180 \mathrm{~m}$.

420 Locations are shown on Figure 1

421

422

423

424

425

426

427

428

429

430

431

432

433

434

435

436

437

438

439

440

441

442

443

444

445

446

447

448

449

450

451

\subsection{Inferred sequence of events}

These observations provide some insight on the complex sequence of events that followed the earthquake and suggest the following scenario. After the $M_{w} 4.7$ 09/24/2019 a turbid cloud formed east of the instrument and drifted slowly. Considering the maximum velocity of the current (less than $4 \mathrm{~cm} / \mathrm{s}$ ) and the 4-hours interval between the earthquake and the passing of the turbid cloud over the instrument, the front of turbid water should have formed ENE of the instrument at a maximum distance of about $500 \mathrm{~m}$, and this coincides with the base of the northern slope near the outlet of the canyon. It is suspected that instability on the steeper slopes on the sides of the canyon is the primary cause of sediment suspension. The clouds subsequently drifted downslope over a total horizontal distance of at most 1 kilometers before dissipating, adding the $500 \mathrm{~m}$ estimate above to the drift calculated after the passing of the front over the instrument (Figure 6).

The $M_{w} 5.8$ 09/26/1919 caused much stronger currents. After the passing of the seismic wave, triggering of instability on slopes adjacent to the deployment site caused mud flows that spread on the basin floor causing the tilting of the instrument 25 minutes after the earthquake, and bottom water turbidity. As the base of the nearest slope is about $400 \mathrm{~m}$ north of the instrument, this would imply a minimum velocity of $20 \mathrm{~cm} / \mathrm{s}$ for the mudflow to reach the device location in 25 minutes. During the following 10 hours, the current record is incomplete but indicates variations in strength and direction. Widespread slope instabilities triggered by the earthquake may have resulted in several turbidity currents recorded as succesive pulses. The role of seiches and surface gravity waves in sediment resuspension can be ruled out as no tsunami was recorded by near shore tidal gauges around the Sea of Marmara. The relationship between gravity wave amplitude $A$ and bottom current amplitude $U$ in the shallow water linear approximation is given by $\mathrm{U}=(\mathrm{g} / \mathrm{H})^{1 / 2} \mathrm{~A}$, where $\mathrm{H}$ is water column height. An oscillatory current of $10 \mathrm{~cm} / \mathrm{s}$ at $1200 \mathrm{~m}$ depth would thus correspond to a free surface oscillation of $1 \mathrm{~m}$ (or $100 \mathrm{hPa}$ ) for a standing wave (seiche) as well as a progressive wave (tsunami). This should have been easily detected in a sea where tidal amplitude is about $10 \mathrm{~cm}$ (Alpar and Yüce, 1998). The influence of baroclinic internal waves on 
452 the halocline at $20-30 \mathrm{~m}$ depth must also be ruled out as they cannot physically produce currents of more than a few $\mathrm{cm} / \mathrm{s}$ at $1200 \mathrm{~m}$. However, It remains possible

454 that the interface at the top of the turbid cloud is affected by baroclinic waves. The

455 strongest current is recorded after 10 hours, which suggests that a turbidity current 456 initiated further upslope may have reached the site after a longer delay but may also 457 have gained more kinetic energy on its downhill path. This event, reaching a speed 458 exceeding $25 \mathrm{~cm} / \mathrm{s}$ apparently caused enough erosion to free the device from the mud 459 accumulation. The current then stabilizes in a westward direction and decays 460 progressively over the next 9 hours, which suggests the tail of a turbidity current flowing 461 in the canyon E of the deployment site has been recorded. The hours-long delay 462 between the earthquake and the passing of the fastest current over the instrument may 463 hypothetically correspond to the time for the head of the turbidity current to travel from 464 its source to the location of the instrument. The length of the canyon valley between 465 the device location and the $400 \mathrm{~m}$ isobath, inferred to be the minimum depth of the 466 turbid water source, is about $13 \mathrm{~km}$. In this scenario, the average velocity of the head 467 of the turbidity current would be $30-40 \mathrm{~cm} / \mathrm{s}$. Alternatively, a sequence of slope failures may have lasted up to several hours after the earthquake. The distance travelled by 469 the turbidity current on the basin floor beyond the instrument may be estimated from 470 the calculated drift during the waing phase, and is found to be about $3.5 \mathrm{~km}$ (Figure 6). 471 When plotted over the bathymetric map the drift appears to stay within the depositional 472 fan at the outlet of the cayon, the extension of which is known from sediment sounder 473 profiles (Figure 1). These calculations are only a rough estimate of the distance 474 travelled by suspended particles as only the velocity at $1.5 \mathrm{~m}$ above the seafloor is 475 known. However, it appears unlikely that sediments spread all over the $15 \times 20 \mathrm{~km}$ basin 476 floor as this would require velocities of the order of $1 \mathrm{~m} / \mathrm{s}$, sustained over a wide area 477 for several hours.

478 The decay of the backscatter signal strength over the next 3 days may reflect 479 the settling of sand size particles put in suspension in the water column after this 480 sequence of events. For a first order assessment, Stokes settling velocity, an upper 481 bound valid in dilute suspensions (e.g. Guazelli and Morris, 2012) may be used. The 482 Stokes settling velocity of $63 \mu \mathrm{m}$ quartz grains (density $2650 \mathrm{~kg} / \mathrm{m}^{3}$ ) in $13^{\circ} \mathrm{C}$ seawater 483 is $2.7 \mathrm{~mm} / \mathrm{s}$, allowing such grains to drop by $700 \mathrm{~m}$ in 3 days. However, if the particles 484 forming the cloud are mostly composed of clay agregates, which density may be 485 comprised between 1200 and $1700 \mathrm{~kg} / \mathrm{m}^{3}$, the settling velocity would be comprised 
between $0.3 \mathrm{~mm}$ and $1 \mathrm{~mm} / \mathrm{s}$. In this case the height of the suspended particle cloud could range between 70 and $250 \mathrm{~m}$.

488

489

490

491

492

493

494

495

496

497

498

499

500

501

502

503

504

505

506

507

508

509

510

511

512

513

514

515

516

517

518

\section{Discussion and conclusion}

Data obtained with a seafloor device located at the oultet of a canyon in the Central Basin in the Sea of Marmara bring some insight on how earthquakes scale with their hydrodynamic consequences. In September 2019, $M_{w} 4.7$ and 5.8 earthquakes occurred at a $5 \mathrm{~km}$ distance from the device as well as a series of smaller foreshocks and aftershocks In this setting, earthquakes of magnitude less than 4 did not cause noticeable water column turbidity nor currents. The $M_{w} 4.7$ earthquake generated a turbid cloud on slopes a few hundred meters from the instrument and the cloud took 3-4 hours to drift down to the instrument location and 10 more hours to dissipate. As the current velocity remained small (less than $4 \mathrm{~cm} / \mathrm{s}$ ), it can be concluded that this cloud did not evolve into a self-sustained turbidity current (Parker, 1982). The $M_{w} 5.8$ earthquake initiated a turbidity current and the data obtained may be compared with more complete records of turbidity currents obtained elsewhere with ADCP deployments and/or water column mooring lines. The duration of the event in the Sea of Marmara (about 10 hours) appear fairly typical and comparable with events recorded in other locations regardless of the initiation mechanism, which comprise hyperpycnal flows from river floods (Var and Gaoping canyons), storm waves and dredging (Gulf of St Laurence and Monterey canyon), and slope instabilities triggered by an earthquake (Tokachi-oki) or by other processes (Var canyon) (Normandeau et al., 2019; Khripounoff et al., 2012; Xu et al., 2004; Liu et al., 2012; Mikada et al., 2006). Longer duration events with very different hydrodynamic characteristics have been observed in larger scale systems (e.g. Congo deep sea canyon, Azpiroz-Zabala et al., 2017). On the other hand, events recorded closer to shore on the edge of the continental shelf or on a delta front have much shorter durations (Xu et al., 2010; Hughes Clarke, 2016). In events of comparable scale to the Sea of Marmara one, the velocity of the current generally reaches its maximum several meters above the seafloor, so that the velocity recorded by our instrument at $1.5 \mathrm{~m}$ from the seafloor is within the boundary layer, and lower than either the maximum current velocity or the velocity of the head of the turbidity current. A velocity of several tens of centimeter per second is representative of the slower recorded examples, corresponding to mud rich flows associated with hyperpycnal flows, to the smaller landslides (Khripounoff et al. 2012) or to the smaller 
519 storm-related events (Normandeau et al., 2019). Turbidites following large earthquakes or large slope instabilities have reached maximum velocities of $20 \mathrm{~m} / \mathrm{s}$

521 (Piper et al., 1999). Velocities of 2-7 m/s were reported for the turbidity current following

522 Tohoku earthquake (Arai et al., 2013) and $1.4 \mathrm{~m} / \mathrm{s}$ in the Tokachi-Oki case (Mikada et

523 al., 2006). The downward current after the off-Izu Penninsula earthquake may be constrained with a noisy ADCP record to a maximum of $10-15 \mathrm{~cm} / \mathrm{s}$ in a $20-30$ m layer above the seafloor and lasted about one hour, peaking about 30 minutes after the earthquake (Kasaya et al., 2009). This turbidity current thus appears less intense and shorter in duration than the one recorded in the Sea of Marmara, but the triggering earthquake was also smaller (M5.4 compared to M5.8) and more distant (10 km). These observations suggest that a general scaling relationship could exist between earthquake magnitudes and the strength and extent of the turbidity currents they induce. Moreover, although the off-Izu event is shorter than the Sea of Marmara one, they share an important characteristic in that the turbid cloud is observed to form when a mud flow hits the observatory site and some time before current builds up in the water column.

The 10 hours delay observed in the Sea of Marmara between the triggering event and the peak of the turbidity current is long compared to the 2 hours delay observed after Tohoku and Tokachi-oki earthquakes. We suggested earlier that the long delay may simply result from a slower velocity of the turbidity current or from delayed slope failure. Another possibility is delayed ignition, which may occur if the turbidity current develops indirectly from the hydrodynamic instability of a turbid cloud resulting from slope failures and/or ground shaking rather than by acceleration of a dense mud flow (Parker, 1982; Mulder and Cochonnat, 1996; Piper and Normark, 543 2009).

544 The scenario we propose for the Sept 26, 2019 earthquake involving mud flows 545 from proximal sources, followed by turbidity currents originating at larger distances, 546 and the subsequent settling of sediment in suspension, could relate with the structure 547 of turbidite-homogenites. Progressive or pulsed build-up of turbidity current energy is 548 considered typical of hyperpycnal flows initiated by river floods (Mulder et al., 2003) 549 but reverse grading and pulsing is also observed in seismoturbidites (Gutierrez-Pastor 550 et al., 2013). In the Sea of Marmara, many of the laminated turbidites sampled in 551 Kumburgaz Basin formed from the amalgamation (below the homogenite layer) of at 552 least two flows, the first one being finer and less sorted (Yakupoğlu et al., 2019). The 
553 coarsening observed in this context is often associated with an increase of the calcium content indicative of a shallower source, rich in biogenic carbonate material. However, in the case observed in the present study, remobilization of sediment should be limited to the lower slope as the temperature of the displaced water precludes a source shallower than $400 \mathrm{~m}$ water depth.

The geomorphological context of the deployment site south of a slope identified as unstable from geomorphological criteria (Zitter et al., 2012), and on a depositional fan at the outlet of a canyon is also consistent with the proposed scenario. We estimated by integrating recorded current velocity that the current during this event was not strong enough to spread the sediment over the entire Central Basin floor but that the zone of deposition was probably comparable in size to the fan. It can be inferred that the paleoseismological record from a core taken in the fan should contain more events than one taken at the basin depocenter. A sediment sounder profile

566 (Figure 1) also shows that the character of the seismic reflectors differs in the basin and in the fan and that establishing reliable correlations between them is not simple. However, as hypothesized by previous studies (McHugh et al., 2014), turbiditehomogenite deposits that can be correlated between cores taken at various locations

570 in the basin probably correspond to the larger events, which may be correlated with

571 historical earthquakes. Moreover, it is still unknown whether the Sept 26 event left a 572 trace on the seafloor morphology and in the sediment record. Performing new core 573 sampling and very high-resolution geophysical surveys in this area would thus have

574 important implications for the understanding of seismoturbidite records and for the 575 assessment of geohazards.

576

577 Acknowledgements

578 Financial support was provided by the bilateral ANR/TÜBITAK collaborative research 579 project MAREGAMI (ANR-16-CE03-0010-02 and Tübitak Project 116Y371) and by

580 CNRS-INSU through the European Multidisciplinary Sea Observatory (EMSO)

581 Research Infrastructure program. DT-INSU and Istanbul Technical University

582 hydrodynamic engineering department provided technical support for device design,

583 construction, and deployment. Bernard Mercier de Lépinay provided processed

584 sediment sounder profiles. We thank the crew and Captain of R/V Yunus (Istanbul

585 University) for their support during installation and recovery of the instruments. 
Alpar, B., \& Yüce, H. (1998). Sea-level variations and their interactions between the Black Sea nd the Aegean Sea. Estuarine, Coastal and Shelf Science, 46, 609-619.

Arai, K., Naruse, H., Miura, R., Kawamura, K., Hino, R., Ito, Y., Inazu, D., Yokokawa, M., Izumi, N., Murayama, M., \& Kasaya, T. (2013). Tsunami-generated turbidity current of the 2011 Tohoku-Oki earthquake. Geology, 41(11), 1195-1198. https://doi.org/10.1130/G34777.1

Armijo, R., Meyer, B., Navarro, S., King, G., \& Barka, A. (2002). Asymmetric slip partitioning in the Sea of Marmara pull-apart: a clue to propagation processes of the North Anatolian Fault? Terra Nova, 14(2), 80-86. https://doi.org/10.1046/j.1365-3121.2002.00397.x

Armijo, R. and J. Malavieille (2002) MARMARASCARPS cruise, RV L'Atalante, https://doi.org/10.17600/2010140 A., Simmons, S. M., Cooper, C., \& Pope, E. L. (2017). Newly recognized turbidity current structure can explain prolonged flushing of submarine canyons. Science Advances, 3(10). https://doi.org/10.1126/sciadv.1700200

Beck, C., Mercier de Lépinay, B., Schneider, J. L., Cremer, M., Çağatay, N., Wendenbaum, E., et al. (2007). Late Quaternary co-seismic sedimentation in the Sea of Marmara's deep basins. Sedimentary Geology, 199, 65-89. https://doi.org/10.1016/j.sedgeo.2005.12.031

Beşiktepe, Ş. T., Sur, H. I., Özsoy, E., Latif, M. A., Oǧuz, T., \& Ünlüata, Ü. (1994). The circulation and hydrography of the Marmara Sea. Progress in Oceanography, 34(4), 285-334. https://doi.org/10.1016/0079-6611(94)90018-3

Brizuela, N., Filonov, A., \& Alford, M. H. (2019). Internal tsunami waves transport sediment released by underwater landslides. Scientific Reports, 9(1), 10775. https://doi.org/10.1038/s41598-019-47080-0

Bulut, F., Aktuğ, B., Yaltırak, C., Doğru, A., \& Özener, H. (2019). Magnitudes of future large earthquakes near Istanbul quantified from 1500 years of historical earthquakes, presentday microseismicity and GPS slip rates. Tectonophysics, 764(July 2018), 77-87. https://doi.org/10.1016/j.tecto.2019.05.005

Çağatay, M. N., Erel, L., Bellucci, L. G., Polonia, a., Gasperini, L., Eriş, K. K., Sancar, Ü., Biltekin, D., Uçarkuş, G., Ülgen, U. B., \& Damci, E. (2012). Sedimentary earthquake 

https://doi.org/10.1016/j.sedgeo.2012.10.001

Çağatay, N. M., Ucarkus, G., Eris, K. K., Henry, P., Gasperini, L., \& Polonia, A. (2015). Submarine canyons of the Sea of Marmara. In F. Briand (Ed.), Submarine Canyon Dynamics in the Mediterranean and Tributary Seas, CIESM Workshop Monograph $\mathrm{n}^{\circ} 47$ (pp. 123-135). CIESM Publisher, Monaco. https://doi.org/10.13140/RG.2.1.1692.8402

Cattaneo, A., Babonneau, N., Ratzov, G., Dan-Unterseh, G., Yelles, K., Bracane, R., Mercier De Lapinay, B., Boudiaf, A., \& Daverchare, J. (2012). Searching for the seafloor signature of the 21 May 2003 Boumerdas earthquake offshore central Algeria. Natural Hazards and Earth System Science, 12(7), 2159-2172. https://doi.org/10.5194/nhess12-2159-2012

Dan, G., Sultan, N., Savoye, B., Deverchere, J., \& Yelles, K. (2009). Quantifying the role of sandy-silty sediments in generating slope failures during earthquakes: Example from the Algerian margin. International Journal of Earth Sciences, 98(4), 769-789. https://doi.org/10.1007/s00531-008-0373-5

Drab, L., Hubert Ferrari, A., Schmidt, S., \& Martinez, P. (2012). The earthquake sedimentary record in the western part of the Sea of Marmara, Turkey. Natural Hazards and Earth System Science, 12(4), 1235-1254. https://doi.org/10.5194/nhess-12-1235-2012

Drab, L., Hubert-Ferrari, A., Schmidt, S., Martinez, P., Carlut, J., \& El Ouahabi, M. (2015). Submarine Earthquake History of the Çınarcık Segment of the North Anatolian Fault in the Marmara Sea, Turkey. Bulletin of the Seismological Society of America, 105(2A), 622-645. https://doi.org/10.1785/0120130083

Eriş, K. K., Çağatay, N., Beck, C., Mercier de Lepinay, B., \& Corina, C. (2012). LatePleistocene to Holocene sedimentary fills of the Çinarcik Basin of the Sea of Marmara. Sedimentary Geology, 281, 151-165. https://doi.org/10.1016/j.sedgeo.2012.09.001

Garfield, N., Rago, T. A., Schnebele, K. J., \& Collins, C. A. (1994). Evidence of a turbidity current in Monterey Submarine Canyon associated with the 1989 Loma Prieta earthquake. Continental Shelf Research, 14(6), 673-686. https://doi.org/10.1016/02784343(94)90112-0

Goldfinger, C., Nelson, C. H., \& Johnson, J. E. (2003). Holocene earthquake records from the cascadia subduction zone and northern san andreas fault based on precise dating of offshore turbidites. Annual Review of Earth and Planetary Sciences, 31(1), 555-577. https://doi.org/10.1146/annurev.earth.31.100901.141246

Goldfinger, C., Nelson, C. H., Morey, A. E., Johnson, J. E., Patton, J., Karabanov, E., Gutiérrez-Pastor, J., Eriksson, A. T., Gràcia, E., Dunhill, G., Enkin, R. J., Dallimore, A., \& Vallier, T. (2012). Earthquake Hazards of the Pacific Northwest Coastal and Marine Regions Turbidite Event History — Methods and Implications for Holocene 
658

659

660

661

662

663

664

665

666

667

668

669

670

671

672

673

674

675

676

677

678

679

680

681

682

683

684

685

686

687

688

689

690

691

692

693

Paleoseismicity of the Cascadia Subduction Zone Professional Paper 1661 - F. USGS, Professional Paper 1661-F, 170. Retrieved from http://pubs.usgs.gov/pppp1661f/

Grall, C., Henry, P., Tezcan, D., Mercier de Lepinay, B., Becel, A., Geli, L., Rudkiewicz, J.-L., Zitter, T., \& Harmegnies, F. (2012). Heat flow in the Sea of Marmara Central Basin: Possible implications for the tectonic evolution of the North Anatolian fault. Geology, 40(1), 3-6. https://doi.org/10.1130/G32192.1

Guazzelli, E., Morris, J. F., \& Pic, S. (2011). A Physical Introduction to Suspension Dynamics. Cambridge: Cambridge University Press. https://doi.org/10.1017/СВO9780511894671

Guerrero, M., Rüther, N., \& Szupiany, R. N. (2012). Laboratory validation of acoustic Doppler current profiler (ADCP) techniques for suspended sediment investigations. Flow Measurement and Instrumentation, 23(1), 40-48. https://doi.org/10.1016/j.flowmeasinst.2011.10.003

Guerrero, M., Szupiany, R. N., \& Amsler, M. (2011). Comparison of acoustic backscattering techniques for suspended sediments investigation. Flow Measurement and Instrumentation, 22(5), 392-401. https://doi.org/10.1016/j.flowmeasinst.2011.06.003

Gutiérrez-Pastor, J., Nelson, C. H., Goldfinger, C., \& Escutia, C. (2013). Sedimentology of seismo-turbidites off the Cascadia and northern California active tectonic continental margins, northwest Pacific Ocean. Marine Geology, 336, 99-119. https://doi.org/10.1016/j.margeo.2012.11.010

Hébert, H., Schindelé, F., Altinok, Y., Alpar, B., \& Gazioglu, C. (2005). Tsunami hazard in the Marmara Sea (Turkey): A numerical approach to discuss active faulting and impact on the Istanbul coastal areas. Marine Geology, 215, 23-43. https://doi.org/10.1016/j.margeo.2004.11.006

Heezen, B. C., Ericson, D. B., \& Ewing, M. (1954). Further evidence for a turbidity current following the 1929 Grand banks earthquake. Deep Sea Research (1953), 1(4), 193-202. https://doi.org/10.1016/0146-6313(54)90001-5

Henry, P., A.M.C. Şengör, M.N. Çağatay (2007) MARNAUT cruise, RV L'Atalante, https://doi.org/10.17600/7010070

Henry, P., Özeren M.S., Desprez De Gesincourt O., de Saint-Leger E., Libes,, M., Çakir, Z., Yakupoğlu, N., Géli, L. (2021). EMSO / MAREGAMI Marmara bottom pressure and current records. SEANOE. https://doi.org/10.17882/78928

Hsu, S. K., Kuo, J., Lo, C. L., Tsai, C. H., Doo, W. Bin, Ku, C. Y., \& Sibuet, J. C. (2008). Turbidity currents, submarine landslides and the 2006 Pingtung earthquake off SW Taiwan. Terrestrial, Atmospheric and Oceanic Sciences, 19(6), 767-772. https://doi.org/10.3319/TAO.2008.19.6.767(PT) 
694

695

696

697

698

699

700

701

702

703

704

705

706

707

708

709

710

711

712

713

714

715

716

717

718

719

720

721

722

723

724

725

726

727

728

729

730

Hughes Clarke, J. E. (2016). First wide-angle view of channelized turbidity currents links migrating cyclic steps to flow characteristics. Nature Communications, 7(1), 11896. https://doi.org/10.1038/ncomms11896

Ikehara, K., Kanamatsu, T., Nagahashi, Y., Strasser, M., Fink, H., Usami, K., et al. (2016). Documenting large earthquakes similar to the 2011 Tohoku-oki earthquake from sediments deposited in the Japan Trench over the past 1500 years. Earth and Planetary Science Letters, 445, 48-56. doi:10.1016/j.epsl.2016.04.009

Karabulut, H., Güvercin, S. E., Eskikoÿ, F., Konca, A. Ö., \& Ergintav, S. (2021). The moderate size 2019 September Mw5.8 Silivri earthquake unveils the complexity of the Main Marmara Fault shear zone. Geophysical Journal International, 224(1), 377-388. https://doi.org/10.1093/gji/ggaa469

Kasaya, T., Mitsuzawa, K., Goto, T., Iwase, R., Sayanagi, K., Araki, E., Asakawa, K., Mikada, H., Watanabe, T., Takahashi, I., \& Nagao, T. (2009). Trial of Multidisciplinary Observation at an Expandable Sub-Marine Cabled Station "Off-Hatsushima Island Observatory" in Sagami Bay, Japan. Sensors, 9(11), 9241-9254. https://doi.org/10.3390/s91109241

Khripounoff, A., Crassous, P., Lo Bue, N., Dennielou, B., \& Silva Jacinto, R. (2012). Different types of sediment gravity flows detected in the Var submarine canyon (northwestern Mediterranean Sea). Progress in Oceanography, 106, 138-153. https://doi.org/10.1016/j.pocean.2012.09.001

Le Pichon, X., Chamot-Roooke, N., Rangin, C., \& Sengör, A. M. C. (2003). The North Anatolian fault in the Sea of Marmara. Journal of Geophysical Research, 108, 2179. https://doi.org/10.1029/2002JB001862

Le Pichon, X., Şengör, A. M. C., Demirbağ, E., Rangin, C., İmren, C., Armijo, R., Görür, N., Çağatay, N., Mercier de Lepinay, B., Meyer, B., Saatçılar, R., \& Tok, B. (2001). The active Main Marmara Fault. Earth and Planetary Science Letters, 192(4), 595-616. https://doi.org/10.1016/S0012-821X(01)00449-6

Liu, J. T., Wang, Y.-H., Yang, R. J., Hsu, R. T., Kao, S.-J., Lin, H.-L., \& Kuo, F. H. (2012). Cyclone-induced hyperpycnal turbidity currents in a submarine canyon. Journal of Geophysical Research: Oceans, 117(C4), n/a-n/a. https://doi.org/10.1029/2011JC007630

McHugh, C. M. G., Seeber, L., Cormier, M. H., Dutton, J., Cagatay, N., Polonia, A., Ryan, W. B. F., \& Gorur, N. (2006). Submarine earthquake geology along the North Anatolia Fault in the Marmara Sea, Turkey: A model for transform basin sedimentation. Earth and Planetary Science Letters, 248, 661-684. https://doi.org/10.1016/j.epsl.2006.05.038 McHugh, C. M., Seeber, L., Braudy, N., Cormier, M. H., Davis, M. B., Diebold, J. B., Dieudonne, N., Douilly, R., Gulick, S. P. S., Hornbach, M. J., Johnson, H. E., Mishkin, K. 

sedimentary effects of the 12 January 2010 Haiti earthquake. Geology, 39(8), 723-726. https://doi.org/10.1130/G31815.1 Henry, P. (2014). Seafloor fault ruptures along the North Anatolia Fault in the Marmara Sea, Turkey: Link with the adjacent basin turbidite record. Marine Geology, 353, 65-83. https://doi.org/10.1016/j.margeo.2014.03.005

Mikada, H., Mitsuzawa, K., Matsumoto, H., Watanabe, T., Morita, S., Otsuka, R., Sugioka, H., Baba, T., Araki, E., \& Suyehiro, K. (2006). New discoveries in dynamics of an M8 earthquake-phenomena and their implications from the 2003 Tokachi-oki earthquake using a long term monitoring cabled observatory. Tectonophysics, 426(1-2), 95-105. https://doi.org/10.1016/j.tecto.2006.02.021

Mulder, T., \& Cochonnat, P. (1996). Classification of Offshore Mass Movements. SEPM Journal of Sedimentary Research, Vol. 66. https://doi.org/10.1306/D42682AC-2B2611D7-8648000102C1865D

Mulder, T., Syvitski, J. P. M., Migeon, S., Faugères, J.-C., \& Savoye, B. (2003). Marine hyperpycnal flows: initiation, behavior and related deposits. A review. Marine and Petroleum Geology, 20(6-8), 861-882. https://doi.org/10.1016/j.marpetgeo.2003.01.003

Nakajima, T., \& Kanai, Y. (2000). Sedimentary features of seismoturbidites triggered by the 1983 and older historical earthquakes in the eastern margin of the Japan Sea. Sedimentary Geology, 135(1-4), 1-19. https://doi.org/10.1016/S0037-0738(00)00059-2

Normandeau, A., Bourgault, D., Neumeier, U., Lajeunesse, P., St-Onge, G., Gostiaux, L., \& Chavanne, C. (2020). Storm-induced turbidity currents on a sediment-starved shelf: Insight from direct monitoring and repeat seabed mapping of upslope migrating bedforms. Sedimentology, 67(2), 1045-1068. https://doi.org/10.1111/sed.12673

Okal, E. A., \& Synolakis, C. E. (2001). Comment on "Origin of the 17 July 1998 Papua New Guinea Tsunami: Earthquake or Landslide?” by E. L. Geist. Seismological Research Letters, 72(3), 362-366. https://doi.org/10.1785/gssrl.72.3.362

Özeren, M. S., Çağatay, M. N., Postacioğlu, N., Şengör, a. M. C., Görür, N., \& Eriş, K. (2010). Mathematical modelling of a potential tsunami associated with a late glacial submarine landslide in the Sea of Marmara. Geo-Marine Letters, 30, 523-539. https://doi.org/10.1007/s00367-010-0191-1

Parker, G. (1982). Conditions for the ignition of catastrophically erosive turbidity currents. Marine Geology, 46(3-4), 307-327. https://doi.org/10.1016/0025-3227(82)90086-X

Piper, D. J. W., \& Normark, W. R. (2009). Processes That Initiate Turbidity Currents and Their Influence on Turbidites: A Marine Geology Perspective. Journal of Sedimentary Research, 79(6), 347-362. https://doi.org/10.2110/jsr.2009.046 
768

769

770

771

772

773

774

775

776

777

778

779

780

781

782

783

784

785

786

787

788

789

790

791

792

793

794

795

796

797

798

799

800

801

Piper, D. J. W., Cochonat, P., \& Morrison, M. L. (1999). The sequence of events around the epicentre of the 1929 Grand Banks earthquake: initiation of debris flows and turbidity current inferred from sidescan sonar. Sedimentology, 46(1), 79-97. https://doi.org/10.1046/j.1365-3091.1999.00204.x

Polonia, A., Vaiani, S. C., \& De Lange, G. J. (2016). Did the A.D. 365 Crete earthquake/tsunami trigger synchronous giant turbidity currents in the Mediterranean Sea? Geology, 44(3), 191-194. https://doi.org/10.1130/G37486.1

Pope, E. L., Talling, P. J., \& Carter, L. (2017). Which earthquakes trigger damaging submarine mass movements: Insights from a global record of submarine cable breaks? Marine Geology, 384, 131-146. https://doi.org/10.1016/j.margeo.2016.01.009

Şengör, A. M. C., Grall, C., İmren, C., Le Pichon, X., Görür, N., Henry, P., Karabulut, H., \& Siyako, M. (2014). The geometry of the North Anatolian transform fault in the Sea of Marmara and its temporal evolution: implications for the development of intracontinental transform faults. Canadian Journal of Earth Sciences, 51(3), 222-242. https://doi.org/10.1139/cjes-2013-0160

Synolakis, C. E., Bardet, J.-P., Borrero, J. C., Davies, H. L., Okal, E. A., Silver, E. A., Sweet, S., \& Tappin, D. R. (2002). The slump origin of the 1998 Papua New Guinea Tsunami. Proceedings of the Royal Society of London. Series A: Mathematical, Physical and Engineering Sciences, 458(2020), 763-789. https://doi.org/10.1098/rspa.2001.0915

$\mathrm{Xu}$, J. P., Noble, M. A., \& Rosenfeld, L. K. (2004). In-situ measurements of velocity structure within turbidity currents. Geophysical Research Letters, 31(9). https://doi.org/10.1029/2004GL019718

Xu, J. P., Swarzenski, P. W., Noble, M., \& Li, A.-C. (2010). Event-driven sediment flux in Hueneme and Mugu submarine canyons, southern California. Marine Geology, 269(12), 74-88. https://doi.org/10.1016/j.margeo.2009.12.007

Yakupoğlu, N., Uçarkuş, G., Kadir Eriş, K., Henry, P., \& Namık Çağatay, M. (2019). Sedimentological and geochemical evidence for seismoturbidite generation in the Kumburgaz Basin, Sea of Marmara: Implications for earthquake recurrence along the Central High Segment of the North Anatolian Fault. Sedimentary Geology, 380, 31-44. https://doi.org/10.1016/j.sedgeo.2018.11.002

Zitter, T. A. C., Grall, C., Henry, P., Özeren, M. S., Çağatay, M. N., Şengör, A. M. C., Gasperini, L., de Lépinay, B. M., \& Géli, L. (2012). Distribution, morphology and triggers of submarine mass wasting in the Sea of Marmara. Marine Geology, 329-331, 58-74. https://doi.org/10.1016/j.margeo.2012.09.002 